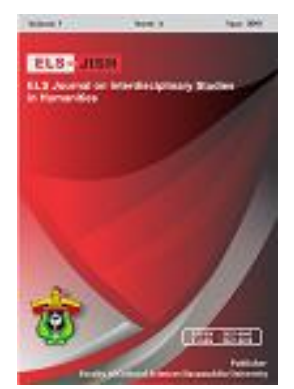

ELS-JISH

ELS Journal on Interdisciplinary Studies on Humanities

Volume 1 Issue 3, 2018

ISSN (print) : 2621-0843

ISSN (online) : 2621-0835

Homepage : http://journal.unhas.ac.id/index.php/jish

\title{
The Effect of Using Scrabble Media on Students' Achievement in Vocabulary
}

\author{
Selamat Husni Hasibuan', Rahma Yanti Pohan² \\ selamathusnihsb@yahoo.com ${ }^{1}$
}

\begin{abstract}
The objectives of the research were to find out the significant effect of Using Scrabble Media which was focused on vocabulary Achievement. The research design in this research was quantitative experimental research. This research was conducted at SMP Negeri 24 Medan in academic years 2017/2018. The population of this research was in the seventh grade students which consisted of eight classes namely: Class VII-A, VII-B, VII-C, VII-D, VII-E, VII-F, VII-G and VII-H. The total numbers of population were 288 students. The research classes were divided into two classes, Experimental Class (36 students) and Control Class (36 students). The technique used was purposive sampling to determine the experimental and control group. The sample were divided into two groups, the first group VII-H which consisted of 36 students was Experimental group which was given treatment by Using Scrabble Media and second group VII-F which consisted of 36 students was Control group which was given treatment by using Conventional Method. Each group was given a pre-test, treatment and post-test. The t-test was 15,71 and the t-table was 1.68 and 0.05 was as the significant level of this research. Because the $t$-test value was higher than $t$-table $(15,71>1.68)$. It showed that the result in t-test was accepted $(\mathrm{Ha})$. Based on the result of this research, it could be concluded that there was significant effect of Using Scrabble Media on the Students' Achievement in vocabulary.
\end{abstract}

Keywords: Scrabble Media, Vocabulary Achievement

How to cite: Hasibuan, S,H, et al. (2018). The Effect of Using Scrabblie Media on Students' achievement in vocabulary. ELS Journal on Interdisciplinary Studies in Humanities, 1(3), 342-349.

\section{Introduction}

Teaching language was not something new for people who had been interested in it since a long time ago. It was caused by the main function of language that was for communication. In the learning process, one of the important parts in creating and understanding the language was vocabulary achievement. People could not express their opinion and ideas in English without knowing vocabulary. Lack vocabulary achievement could make them unable to express the opinion properly. We should learn vocabulary in order to develop our language skills.

Many people dealt with a particular situation by learning specific words related to that context while they had hardly any achievement of grammatical structures. Students who wanted to learn a target language, had to learn those language components. Vocabulary

${ }^{12}$ Universitas Muhammadiyah Sumatera Utara, Indonesia 
was one of the language components which should be learned by English Learners. Vocabulary had role, which parallel with phonology and grammar to help the students to acquire four language skills. Hornby and Crowther (1995) stated that "Vocabulary is the total number of words in language". While according to Richards (2002:580), "Vocabulary is a set of lexemes, including single words, compound words and idioms".

Students usually had many problems in mastering English words. They had limited vocabulary to comprehend the meaning of the a text, they did not know the context of word used in the text, they could not recognize the meaning of each word, they were not able to hear English word from speakers, they could not compose the their writing task successfully, and they got difficulties to state some sentences in English.

Based on the researcher observation and teaching experiece on the seventh grade, students' academic year 2017/2018 at SMPN 24 Medan, the researcher found the problem in vocabulary. The reason of researcher to write this study was because some of students did not have much vocabulary. The researcher observed the students ability in vocabulary. They were still difficult to memorize the unfamiliar words that they heard or read in the text. They did not know what the teacher explained in English. The students also got difficulties to recognize spelling and find the meaning of words.

Based on the case above, the researcher tried to apply a media to solve the problem in teaching vocabulary achievement. The researcher made a creative and new media to make vocabulary was not difficult and always interesting for the students of junior high school in order that they did not feel bored and they became active in the classroom. It was scrabble media. Scrabble was one of the media that could be used to teach vocabulary in Junior High Schools. Using scrabble media in teaching vocabulary would encourage the students to reinforce their vocabulary that they had stored in the brains. When students played scrabble media they did not realize that they were learning English. Students also got new words or vocabulary naturely.

Warner and Brown (2005:2) said that scrabble was proprietary board media, which involved the building of words for point score, for two or more players (or teams). Students got to arrange the letters that they got to produce a meaning. It forced the students to learn the vocabulary easily, store and recall it in memory. It also made the students remember vocabulary faster and better. Using scrabble media would make it easier for students to better understand the vocabulary. Besides being easy, this medium also attracted students to the learning of English.

\section{Method}

In this research, the researcher used an experimental design. It dealt with quantitative method. This research was conducted by using experimental design namely a research to test and prove a hypothesis by giving treatment for the sample. This experimental design was to show whether using scrabble media was better than conventional method.

\subsection{Location}

This research would be conducted at SMP Negeri 24 Medan. The research would be conducted during the academic year 2017/2018. The researcher found the students were not brave to speak English, because they had difficulties in memorizing, spelling, and pronouncing the vocabulary. The research wanted to change the students' behavior in learning English and improved their ability to speak English. Based on that situation, the 
researcher conducted a research about the effect of using scrabble media on students' vocabulary achievement.

\subsection{Population}

The population of this research was the seventh grade of SMP Negeri 24 Medan, which consisted of eight parallel classes with 288 students of VII-A, VII-B, VII-C, VII-D, VIIE, VII-F, VII-G, VII-H.

\subsection{The Technique for Collecting the Data}

The data were collected by giving the test to the students. Several steps would be used to collect the data, as follow

1. Giving Pre-test to Experimental and Control group

2. Giving Treatment to Experimental group by using Scrabble media

3. Giving Post-test Experimental and Control group

4. Correcting the students' answer sheet

\subsection{The Technique of Data Analysis}

In analyzing the data, the result of the data were analyzed by using statical procedure which consisted of mean, standard deviation (SD) and dependent test. The mean used to find out the average of the sample. To find the mean, Ary Jacobs (2010) stated:

a. Mean

$$
\overline{\mathrm{X}}=\frac{\sum \mathrm{X}}{\mathrm{N}}
$$

Where:

$$
\begin{array}{ll}
\overline{\mathrm{x}} & =\text { mean } \\
\Sigma & =\text { sum of } \\
\mathrm{X} & =\text { raw score } \\
\mathrm{N} & =\text { number of cases }
\end{array}
$$

\section{Discussion}

The data of the study were the students' score in the pre-test and post-test in the experimental class. The experimental class was given pre-test and post-test consisting 20 items.

\subsection{Calculating the data using formula}

After the researcher assessed students' scores, then they were calculated into formulas to find out Standard Deviation and T-test to know the differences between the students' score in the experimental group and control group, it could be seen in the tables below: 
Tables 4.1 The Students' Score Pre-Test and Post-Test of the Experimental Group

\begin{tabular}{|c|c|c|c|c|c|}
\hline \multirow[t]{2}{*}{ No } & \multirow{2}{*}{$\begin{array}{c}\text { Students intial } \\
\text { names }\end{array}$} & \multicolumn{2}{|c|}{ Score } & \multirow[t]{2}{*}{$D(x 2-x 1)$} & \multirow[t]{2}{*}{$\mathrm{D}^{2}$} \\
\hline & & Pre-test & Post-test & & \\
\hline 1 & ARF & 60 & 85 & 25 & 625 \\
\hline 2 & AK & 70 & 85 & 15 & 225 \\
\hline 3 & AA & 60 & 80 & 20 & 400 \\
\hline 4 & BP & 55 & 80 & 25 & 625 \\
\hline 5 & $\mathrm{CRH}$ & 65 & 75 & 10 & 100 \\
\hline 6 & CS & 60 & 75 & 10 & 100 \\
\hline 7 & $\mathrm{CO}$ & 75 & 85 & 10 & 100 \\
\hline 8 & $\mathrm{MKH}$ & 45 & 85 & 40 & 1600 \\
\hline 9 & DS & 45 & 80 & 35 & 1225 \\
\hline 10 & ET & 70 & 80 & 10 & 100 \\
\hline 11 & FAD & 65 & 85 & 20 & 400 \\
\hline 12 & FM & 60 & 85 & 20 & 400 \\
\hline 13 & HSN & 60 & 80 & 20 & 400 \\
\hline 14 & IS & 45 & 75 & 30 & 900 \\
\hline 15 & MAF & 65 & 85 & 20 & 400 \\
\hline 16 & MAU & 70 & 85 & 15 & 225 \\
\hline 17 & FS & 65 & 80 & 15 & 225 \\
\hline 18 & MN & 60 & 85 & 25 & 625 \\
\hline 19 & NS & 45 & 80 & 35 & 1225 \\
\hline 20 & NRZ & 45 & 80 & 35 & 1225 \\
\hline 21 & PP & 50 & 85 & 35 & 1225 \\
\hline 22 & $\mathrm{Ml}$ & 45 & 85 & 40 & 1600 \\
\hline 23 & HAS & 60 & 85 & 25 & 625 \\
\hline 24 & RPP & 60 & 85 & 25 & 625 \\
\hline 25 & $\mathrm{RC}$ & 65 & 80 & 15 & 225 \\
\hline 26 & ST & 60 & 80 & 20 & 400 \\
\hline 27 & ES & 70 & 85 & 15 & 225 \\
\hline 28 & $\mathrm{RS}$ & 60 & 75 & 15 & 225 \\
\hline 29 & JS & 70 & 85 & 15 & 225 \\
\hline 30 & VM & 75 & 85 & 10 & 100 \\
\hline 31 & WG & 70 & 80 & 10 & 100 \\
\hline 32 & $\mathrm{JZ}$ & 65 & 85 & 20 & 400 \\
\hline 33 & PT & 70 & 90 & 30 & 900 \\
\hline 34 & JRT & 60 & 85 & 25 & 625 \\
\hline 35 & IL & 70 & 90 & 30 & 900 \\
\hline 36 & MP & 65 & 85 & 20 & 400 \\
\hline & Total & 2200 & 2975 & 792 & 19925 \\
\hline & Mean & 61.11 & 82.63 & 22 & 553 \\
\hline
\end{tabular}

The table above showed students' name (sample) and the total score. The total score of pretest was 2200 and the mean was 61,11 . In post-test, the total score was 2975 and the mean of the score was 82,63 . The researcher analyzed Standard Deviation to know differences between pretest and post-test. So, the researcher used formula below:

$$
S_{D}=\sqrt{\frac{\sum D^{2}-\frac{(\Sigma D)^{2}}{n}}{N-1}}
$$




$$
\begin{aligned}
& =\sqrt{\frac{19925-\frac{(792)^{2}}{36}}{36-1}} \\
& =\sqrt{\frac{19925-\frac{627264}{36}}{35}} \\
& =\sqrt{\frac{19925-17424}{35}} \\
& =\sqrt{\frac{2501}{35}} \\
& =\sqrt{71,45} \\
& =8,45
\end{aligned}
$$

So, Standard deviation of experimental group was 8,45 . Thus, those values could be used to find out the result of applying t-test formula. It could be seen in the following:

$$
t=\sqrt{\frac{\bar{D}}{\frac{\sum D^{2}-\frac{\left(D^{D}\right)^{2}}{N}}{N(N-1)}}}
$$

22

$$
\sqrt{\frac{19925-\frac{(792)^{2}}{86}}{36(36-1)}}
$$

$$
\frac{22}{\sqrt{\frac{19925-\frac{627264}{86}}{36(35)}}}
$$

$$
\begin{aligned}
& \frac{22}{\sqrt{\frac{19925-17424}{1260}}} \\
& \frac{22}{\sqrt{\frac{2501}{1260}}} \\
& \frac{22}{\sqrt{1,98}} \\
& \frac{22}{1,40} \\
& t=15,71
\end{aligned}
$$


The result of calculation showed that t-test was 15,71 and t-table was 1.68. The t-test was higher than t-table $(15,71>1.68)$. After knowing the students' scores in the experimental group, then the researcher calculated it in Standard Deviation and t-test to know the students' score in control group, it could be seen in the tables below:

Tabel 4.2 The Students' Score Pre-Test and Post-Test of the Control Group

\begin{tabular}{|c|c|c|c|c|c|}
\hline \multirow[t]{2}{*}{ No } & \multirow[t]{2}{*}{ Students intial names } & \multicolumn{2}{|c|}{ Score } & \multirow[t]{2}{*}{$D(x 2-x 1)$} & \multirow[t]{2}{*}{$D^{2}$} \\
\hline & & Pre-test & Post-test & & \\
\hline 1 & AVS & 50 & 65 & 15 & 225 \\
\hline 2 & AJS & 45 & 65 & 20 & 400 \\
\hline 3 & $\mathrm{AB}$ & 50 & 65 & 15 & 225 \\
\hline 4 & BPM & 45 & 60 & 15 & 225 \\
\hline 5 & BS & 45 & 65 & 20 & 400 \\
\hline 6 & $\mathrm{CA}$ & 45 & 65 & 20 & 400 \\
\hline 7 & CS & 45 & 65 & 20 & 400 \\
\hline 8 & DP & 60 & 75 & 15 & 225 \\
\hline 9 & DM & 45 & 65 & 20 & 400 \\
\hline 10 & EM & 55 & 70 & 15 & 225 \\
\hline 11 & EVF & 45 & 60 & 15 & 225 \\
\hline 12 & $\mathrm{FE}$ & 45 & 60 & 15 & 225 \\
\hline 13 & $\mathrm{FH}$ & 55 & 65 & 10 & 100 \\
\hline 14 & FNA & 50 & 65 & 15 & 225 \\
\hline 15 & FMS & 60 & 70 & 10 & 100 \\
\hline 16 & FNG & 45 & 55 & 10 & 100 \\
\hline 17 & GJM & 60 & 80 & 20 & 400 \\
\hline 18 & ILR & 50 & 70 & 20 & 400 \\
\hline 19 & JMS & 50 & 70 & 20 & 400 \\
\hline 20 & JR & 50 & 65 & 15 & 225 \\
\hline 21 & LNH & 55 & 75 & 20 & 400 \\
\hline 22 & LB & 45 & 75 & 30 & 900 \\
\hline 23 & MAA & 55 & 70 & 15 & 225 \\
\hline 24 & MDA & 50 & 75 & 25 & 625 \\
\hline 25 & MMD & 60 & 75 & 15 & 225 \\
\hline 26 & MN & 60 & 80 & 20 & 400 \\
\hline 27 & MR & 55 & 70 & 15 & 225 \\
\hline 28 & NRB & 45 & 65 & 20 & 400 \\
\hline 29 & NCZ & 45 & 65 & 20 & 400 \\
\hline 30 & PDT & 60 & 75 & 15 & 225 \\
\hline 31 & PKS & 55 & 70 & 15 & 225 \\
\hline 32 & RAS & 50 & 70 & 20 & 400 \\
\hline 33 & SOG & 55 & 70 & 15 & 225 \\
\hline 34 & SM & 50 & 70 & 20 & 400 \\
\hline 35 & VC & 60 & 85 & 25 & 625 \\
\hline 36 & $\mathrm{YL}$ & 50 & 75 & 25 & 625 \\
\hline & Total & 1850 & 2485 & 612 & 12050 \\
\hline & Mean & 51.38 & 69.02 & 17 & 334.72 \\
\hline
\end{tabular}

Based the table above, it could be concluded that the total score of pre-test was 1850 and the mean was 51, 38. In post-test, the total score was 2485 and the mean of the score was 69,02 . It meant that, the total and mean score in post-test in the experimental group was higher than the total and the mean score in post-test in the control group. To measure 
ISSN: (E) 2621-0835, (P) 2621-0843

Standard Deviation in the control group, the researcher analyzed the data by using formula as follow:

$$
\begin{aligned}
S_{D} & =\sqrt{\frac{\sum D^{2}-\frac{\left(\sum D\right)^{2}}{n}}{N-1}} \\
& =\sqrt{\frac{12050-\frac{(612)^{2}}{36}}{36-1}} \\
& =\sqrt{\frac{12050-\frac{374544}{36}}{35}} \\
& =\sqrt{\frac{12050-10404}{35}} \\
& =\sqrt{\frac{1646}{35}} \\
& =\sqrt{47,02} \\
& =6,85
\end{aligned}
$$

So, Standard Deviation of control group was 6,85 . Thus, those values could be used to find out the result of applying t-test formula. It could be seen in the following:

$$
\begin{gathered}
t=\frac{\bar{D}}{\sqrt{\frac{\sum D^{2} \frac{(\Sigma D)^{2}}{N}}{N(N-1)}}} \\
=\frac{17}{\sqrt{\frac{12050-\frac{(612)^{2}}{36}}{36(36-1)}}} \\
=\frac{17}{\sqrt{\frac{12050-\frac{374544}{36}}{36(35)}}} \\
=\frac{17}{\frac{12050-10404}{1260}} \\
=\frac{17}{\sqrt{\frac{1646}{1260}}}
\end{gathered}
$$




$$
\begin{aligned}
= & \frac{17}{1,14} \\
t & =14,91
\end{aligned}
$$

\subsection{Testing Hypothesis}

In analyzing the hypothesis, it referred to the t-table at the level significant of $\propto 0.05$. The testing criterion used for hypothesis result was: if $\mathrm{t}$-test $>\mathrm{t}$-table, it meant that the alternative hypothesis $(\mathrm{Ha})$ was accepted and null hypothesis $(\mathrm{Ho})$ was rejected. Furthermore, the t-table with the level significant of $\propto 0.05$ with the degree of freedom (df) $\rightarrow(2 n-2=72-2=70)$ was 1.68 . This meant that $\mathrm{Ha}$ in this study was accepted since students' t-test in the experimental group was 15,71 and the t-table was 1.68. Because the t-test value was higher than the t-table $(15,71>1.68)$, it could be concluded that Using Scrabble Media could improve students' achievement in vocabulary

\section{Conclusion}

Based on the finding of the data analysis and the discussion, the conclusion was as follow:

There was significant effect of Using Scrabble Media on students' achievement in vocabulary. The result of computation in t-test was 15,71 , while the critical value of 0.05 significant level was 1.68. The conclusion from the data analysis was the value of t-test $(15,71)$ was higher than the t-table (1.68). It meant that the alternative hypothesis (Ha) was accepted and the teaching by using Scrabble Media more significantly effected on the students' achievement in vocabulary than using Conventional Method.

\section{References}

Ary, D., Jacobs, L. C., Razavie, A., \& Sorensen, C. (2010). Introduction to research in education, (8th ed), Canada: Thomson Wadsworth.

Hornby, A. S., \& Crowther, J. (1995). Oxford Advanced Learner's Dictionary of Current English (5th ed.). Oxford : New Delhi: Oxford University Press.

Richards, J. C., 1943-. (2002). Longman Dictionary of Language Teaching and Applied Linguistics. London ; New York :Longman.

Warner, H \& Brown, P. (2005). Adult ESL students' perceptions of Scrabble as a classroom learning tool. New Zealand: Prospect. 